\title{
Conversos y librepensamiento. A la búsqueda de algunas huellas (ss. XVI y XVII)
}

Markus Schreiber*

HistCom

ORCID ID: http://orcid.org/0000-0002-3301-3241

En los siglos XVI y XVII, en el entorno de los cristianos nuevos ibéricos se detectan algunas manifestaciones radicales de desvinculación religiosa. Prosiguiendo las investigaciones de Yitzhak Baer, Carl Gebhardt y sobre todo de Israël S. Révah, esos fenómenos han sido repetidamente vinculados tanto con el «averroísmo» judío bajomedieval como con la filosofía spinoziana del seiscientos. Sin embargo, nos parecen posibles más enfoques. Aquí, queremos presentar esas corrientes de incredulidad conversa sobre su trasfondo académico y enmarcadas en el contexto europeo, prestando una atención particular a un grupo de cinco médicos cristianos nuevos que, alrededor de 1630, estudiaron juntos en la Universidad de Alcalá de Henares.

Palabras Clave: Cristianos nuevos; Castilla; siglo xvir; deísmo; ateísmo; universidad; Alcalá de Henares; Inquisición.

Conversos and Freethought. Searching for Traces (16th and 17th c.).- In the 16th and 17th centuries, among Iberian New Christians there can be detected some radical manifestations of religious disruption. Following the research of Yitzhak Baer, Carl Gebhardt and most notably Israël S. Révah, these phenomena repeatedly have been linked both to late medieval Jewish «averroism» and the Spinozistic philosophy of the 17th century. However, more perspectives are possible. Here, we would like to present the trends of converso unbelieve with their academic background and in the European context, paying special attention to a group of five New Christian physicians, who, about 1630, together studied at the University of Alcalá de Henares.

Keywords: New Christians; Castile; 17th Century; Deism; Atheism; University; Alcalá de Henares; Inquisition.

\footnotetext{
"markus.schreiber@histcom.de

Copyright: (C) 2017 CSIC. Este es un artículo de acceso abierto distribuido bajo los términos de una licencia de uso y distribución Creative Commons Attribution (CC-by) España 3.0.
} 
Al final de su vida, el hombre prefería la reflexión filosófica en su retiro solitario al bullicio de la cercana Sevilla. Hacia el año 1660, Juan Baptista Piñero (?-1662) vivía en una de las dependencias del monasterio de San Isidro del Campo, donde cuidaba como médico de los religiosos jerónimos. A pesar de su reclusión, el doctor se mantenía enredado en una discusión científica cada vez más enconada acerca del sitio correcto para practicar la sangría. En pocos años, publicó tres escritos al respecto. Hoy, esos libros constituyen los únicos testimonios directos de un portugués que era, según un contemporáneo suyo, «hombre de cortissimo juicio, poco Philosopho y menos Medico [...] y, lo peor, abominable en sus costumbres». No obstante, en sus razonamientos Piñero se revela como persona culta y perspicaz. Y que fuese mal galeno no parece probable a la vista de sus servicios como médico de cámara de la casa de Medina Sidonia en torno a 1655. El argumentum denigrante iba ad hominem para criticar a un espíritu inquieto, que era «loco en su discurir, intrepido en su hablar, amigo de novedades, solicitador de paradoxas». El detractor, Isaac Orobio de Castro (ca. 16171687), en primer término atacaba al «maldito y detestable» Piñero como «seductor» intelectual de Juan de Prado (ca. 1613-1669), quien, a su vez, tenía fama de haber «pervertido» con sus ideas radicales al joven Spinoza ${ }^{1}$.

Israël S. Révah (1917-1973) investigó por primera vez los detalles de la relación entre el doctor Prado y el futuro filósofo holandés. Desde 1959 en adelante, publicó una serie de trabajos importantes acerca del encuentro de ambos en Amsterdam a mediados del siglo XVII, y fue él quien llamó la atención sobre la involucración de un tercer personaje. Sobre este Juan Piñero -al parecer idéntico a nuestro médico de San Isidro del Campo- solamente existían escasas informaciones. Aparte de algunas vagas referencias de la documentación inquisitorial, se conocía la caracterización corta y poco halagüeña que de él escribió Orobio de Castro en 1664. Según el miembro de la comunidad sefardita de Amsterdam, Piñero era «Hebreo de nacion, primero Christiano, despues Judio, y despues ni Judio ni Christiano». Una descripción que también valía para Juan de

\footnotetext{
${ }^{1}$ Quiero agradecer a Pilar Huerga Criado y Roberto López Vela su muy valiosa ayuda en la redacción de este artículo. Las publicaciones de Piñero con las informaciones biográficas se recogen infra en la nota 74. Sobre los testimonios de Isaac Orobio de Castro, véase Israël S. Révah, Spinoza et le Dr Juan de Prado (Paris-The Hague, 1959) págs. 109 y 132 (apéndice documental). Acerca del asunto Piñero-Prado-Spinoza, véase la nota 2.
} 
Prado. Al parecer, ambos hombres perdieron la fe y el primero sería el «corruptor» del segundo, que a su vez «pervertiría» a Spinoza.

Según Révah, la reconstrucción de los orígenes del spinozismo nos conduce directamente a la incredulidad de algunos cristianos nuevos portugueses, y más atrás hasta el «averroísmo» del judaísmo español bajomedieval ${ }^{2}$. La interpretación era novedosa en su momento y sigue siendo seductora; sin embargo, quisieramos ampliar esta «narrativa judía» dándole un enfoque más complejo. Así, presentaremos la desvinculación religiosa de hombres como Juan Baptista Piñero y Juan de Prado no sólo como un fenómeno propio de los cristianos nuevos, sino analizado en el entorno académico en el que se formaron. Además, para captar y situar mejor aquellas manifestaciones de incredulidad, resulta instructiva una perspectiva que se proyecte tanto sobre el contexto ibérico ${ }^{3}$ como sobre el marco europeo.

\section{El FANTASMA DEL ATEÍSMO EN EUROPA}

En cuanto a la historia de la irreligión, se ha desmantelado cualquier gran narrativa ${ }^{4}$ e incluso se han negado formas auténticas de ateísmo en la Europa preilustrada. Un hito de la discusión marcó en 1942 el libro cautivador de Lucien Febvre (1878-1956) sobre el «problema de la incredulidad en el siglo XVI», en el que analiza la «religión de Rabelais» y llega a la conclusión de que la época era tan profundamente cristiana que ni siquiera disponía del lenguaje para formular ideas ateístas ${ }^{5}$. Veinti-

${ }^{2}$ Los trabajos de Israël S. RÉVAH acerca de la temática fueron reunidos y nuevamente publicados en Henri Méchoulan, Pierre-François Moreau y Carsten L. Wilke (eds.), Des marranes à Spinoza (Paris, 1995).

${ }^{3}$ Nos referimos a España, Portugal y sus dominios ultramarinos, pero también a comunidades y personas que - procedentes de esos territorios- se situaban fuera y seguían manteniendo vinculación con las sociedades y culturas ibéricas. Un ejemplo significativo sería la «nación» portuguesa de Amberes; vid. Hans PoHL, Die Portugiesen in Antwerpen (1567-1648). Zur Geschichte einer Minderheit (Wiesbaden, 1977).

${ }^{4}$ Un ejemplo más reciente de esta historiografía «constructiva» se encuentra en Georges Minors, Histoire de l'athéisme - les incroyants dans le monde occidental des origines à nos jours (Paris, 1998).

${ }^{5}$ Lucien Febvre, Le problème de l'incroyance au XVI e siècle. La religion de Rabelais (Paris, 1942).

SEFARAD, vol. 77:2, julio-diciembre 2017, págs. 375-403. ISSN: 0037-0894. doi: 10.3989/sefarad.017.013 
séis años más tarde, Paul Otto Kristeller (1905-1999), en un artículo corto, pero influyente, deconstruyó el «mito del ateísmo renacentista» y su transmisión a la «tradición francesa de librepensamiento» ${ }^{6}$. Y un trabajo más reciente pone en duda de manera generalizada los diversos testimonios medievales acerca de una incredulidad en aquella época ${ }^{7}$.

En 1998, Winfried Schröder (n. 1956) publicó su obra Orígenes del ateísmo, en la que también negó cualquier manifestación atea durante la edad media y el renacimiento; sin embargo, localizó los orígenes del fenómeno ya a mediados del seiscientos. El historiador de filosofía mostró que el Theophrastus redivivus - manuscrito clandestino de un anónimo probablemente francés- inició la serie de textos ateístas basados en una argumentación filosófica. La meticulosa reconstrucción de Schröder es bastante convincente, y resulta interesante cómo relaciona el ateísmo naciente con las ciencias modernas y el deísmo. Esta «religión filosófica», con su fuerte reconocimiento racional de una entidad suprema, no era de ninguna manera una versión «ligera» de la negación radical de Dios. Además, la irreligión extrema no siempre estaba a la altura de los desarrollos filosóficos y científicos de la época, que se compaginaban mejor con una «teología natural» ${ }^{8}$. Ese deísmo, con su rechazo de la revelación divina, surgió antes que el ateísmo. Los comienzos los marca el Colloquium heptaplomeres, que generalmente se data en los años finales del siglo XVI y se atribuye a Jean Bodin (1529/30-1596). En la misma época, el silesio Martin Seidel (ca. 1545-?) escribió el texto Origo et fundamenta religionis Christianae, surgido en un ambiente antitrinitario. Desde entonces, ideas deístas se detectan en diversos contextos de Europa y América, y aunque son casos aislados, superan claramente el número de las manifestaciones ateístas ${ }^{9}$.

\footnotetext{
${ }^{6}$ Paul Otto Kristeller, «The Myth of Renaissance Atheism and the French Tradition of Free Thought», Journal of the History of Philosophy 6 (1968) págs. 233-243.

7 Dorothea Weltecke, «Der Narr spricht: Es ist kein Gott»: Atheismus, Unglauben und Glaubenszweifel vom 12. Jahrhundert bis zur Neuzeit (Frankfurt am Main-New York, 2010).

${ }^{8}$ Winfried SchröDER, Ursprünge des Atheismus. Untersuchungen zur Metaphysikund Religionskritik des 17. und 18. Jahrhunderts (2 ed., Stuttgart, 2012); véase además Tullio Gregory, Theophrastus redivivus. Erudizione e ateismo nel Seicento (Napoli, 1979).

${ }^{9}$ En su obra sobre el ateísmo, Schröder se refiere repetidas veces a este deísmo temprano; véanse también: Winfried ScHRÖDER (ed.), Gestalten des Deismus in Europa 
Con estos hitos, quedan acotadas las zonas tempranas de una desvinculación articulada y radical de la tradición religiosa. Pero ¿qué pasó más allá de los límites? ¿Eran sólo exageración, habladuría y calumnia los constantes ataques contra los «ateístas», «epicúreos» y «maquiavelistas»? En la mayor parte de los casos sí. No obstante, ya en la baja edad media y posteriormente se detectan indudables manifestaciones de un materialismo que, sin mayor elaboración intelectual, cuestionaba las bases religiosas y eclesiásticas ${ }^{10}$. Hasta cierto grado, esa incredulidad tan marginal como subterránea se reflejaba en el tratado fantasmal De tribus impostoribus, que a lo largo de los siglos deambulaba por Europa y sólo en la Alemania de los años finales del siglo XVII se materializó en un texto concreto ${ }^{11}$. Mientras que el ataque contra Moisés, Jesús y Mahoma hacía posibles interpretaciones tanto ateístas como deístas, otra corriente de pensamiento permitía una mayor variedad de conclusiones. Desde el renacimiento, el escepticismo en su forma pirroniana y difundido por los escritos de Sexto Empírico, desplegaba una influencia nada desdeñable y ponía en duda los fundamentos intelectuales y espirituales de las socieda-

(Wiesbaden, 2013) -especialmente la introducción de SCHRÖDER, págs. 7-27; Christopher J. BetTs, Early Deism in France. From the so-called «déistes» of Lyon (1564) to Voltaire's «Lettres philosophiques» (1734) (The Hague et al., 1984) -con una evaluación algo diferente de los inicios; y Wayne Hudson, The English Deists. Studies in Early Enlightenment (London, 2009), y Enlightenment and Modernity. The English Deists and Reform (London, 2009).

${ }^{10}$ Están bien documentados estos casos para toda Europa. Sin embargo, el problema de libros como el de Minors (Histoire de l'athéisme) reside en una falta de diferenciación entre fenómenos que van desde el materialismo popular hasta un auténtico ateísmo basado en una argumentación racional. Así también sucede con Didier Foucault, Histoire du libertinage: des goliards au marquis de Sade (Paris, 2007), y François Berriot, Athéismes et athéistes au XVI siècle en France, 2 tt. (Paris-Lille, 1984). Observaciones mucho más pertinentes sobre el asunto son las del gran medievalista checo František Graus, Pest Geißler-Judenmorde. Das 14. Jahrhundert als Krisenzeit (Göttingen, 1984) págs. 84-86; aparte de lo que encontramos en Michael HunTER y David WootTon (eds.), Atheism from the Reformation to the Enlightenment (Oxford, 1992).

${ }^{11}$ Martin Mulsow, Moderne aus dem Untergrund. Radikale Frühaufklärung in Deutschland, 1680-1720 (Hamburg, 2002) págs. 115-160; no hay que confundir este texto con el «Traité des Trois Imposteurs», sobre el cual véase Silvia BerTi, Françoise CharLesDaubert y Richard H. Popkin (eds.), Heterodoxy, Spinozism, and Free Thought in Early Eighteenth Century Europe. Studies on the Traité des Trois Imposteurs (DordrechtBoston-London, 1996). 
des europeas. Sin embargo, no sólo debilitaba seguridades religiosas sino que también podía desembocar en un fideísmo pronunciado ${ }^{12}$.

Si en los siglos XVI y XVII la falta de fe se manifestaba en unas zonas más o menos bien definidas, la incredulidad se hacía notar también dentro de los razonamientos corrientes y ortodoxos. Alrededor de 1600, estaba disponible todo un arsenal linguiístico y argumentativo con el que realizar una crítica radical de la religión. Los eruditos europeos tenían en el latín una lengua bien desarrollada, y algunos de ellos incluso sabían griego. Además, contaban con la gran herencia escolástica, y se conocían tanto el legado filosófico del pasado grecolatino como los escritos más importantes de las tradiciones islámica y judía ${ }^{13}$. Y es más, fueron los propios teólogos los que difundieron todo tipo de argumentaciones «peligrosas» al denunciar y atacar en sus discusiones internas constantemente a sus adversarios como incrédulos. En el caso de Francia, este fenómeno ha sido estudiado por Alan Kors (n. 1943), que lo define como «ateísmo sin ateístas». Sin embargo, en el entorno de esos enfrentamientos académicos, al final surgieron ateos de carne y hueso como Jean Meslier (1664-1729) con su materialismo radical ${ }^{14}$.

\section{MERCANCÍA ESPIRITUAL EN EL MUNDO IBÉRICO}

En 1611, se publicaron en Bruselas las Diez lamentaciones del miserable estado de los Atheistas de nuestro tiempo. Con este ataque, Jerónimo Gracián (1545-1614) presentaba una serie de categorías y criterios de una «irreligión» que llegaba desde cierto «materialismo epicúreo» hasta una espiritualidad «libre», como se manifestaba en el alumbradismo es-

\footnotetext{
${ }^{12}$ Richard H. PopkIn, The History of Scepticism. From Savanarola to Bayle (ed. orig. 1960 Oxford et al., 2003).

${ }^{13}$ Acerca de las bases filosóficas e intelectuales, véanse Thomas LeinKauf, Grundriss Philosophie des Humanismus und der Renaissance (1350-1600), 2 tt. (Hamburg, 2017); Charles B. Sснмiтt et al. (eds.), The Cambridge History of Renaissance Philosophy (Cambridge et al., 1988), y Eckhard KessLer, Die Philosophie der Renaissance. Das 15. Jahrhundert (München, 2008).

${ }^{14}$ Vid. Alan Charles Kons, Atheism in France, 1650-1729. The Orthodox Sources of Disbelief (Princeton, 1990); Naturalism and Unbelief in France, 1650-1729 (Cambridge, 2016), y Epicureans and Atheists in France, 1650-1729 (Cambridge, 2016).
} 
pañol o en algunos ambientes radicales de la Reforma ${ }^{15}$. La mayor parte del libro de Gracián poco o nada tiene que ver con el ateísmo, pues el carmelita lo enfoca sobre todo en su tercera «Lamentacion», que trata de los «Atheistas Carnales y Epicureos». Como en el resto de Europa, tales manifestaciones están documentadas para el mundo ibérico desde la baja edad media y detectadas en ambientes cristianos, judíos y conversos ${ }^{16}$. Para las autoridades -en España como en otras partes- el «materialismo epicúreo» era un escándalo; sin embargo, su peligrosidad se relativizaba por su muy reducida difusión y por la falta de elaboración intelectual. Además, se trataba de negar la relevancia del fenómeno calificándolo como expresión de una mente trastornada.

Isaac, alias Fernando, Cardoso (1603/04-1683) -personaje clave del mundo intelectual judeoconverso y sefardita del siglo XVII- retomó el tópico en su Philosophia libera (1673). Todos los argumentos del médico y filósofo a favor de la existencia de Dios se dirigen más o menos abiertamente contra los ateos, para culminar con una descalificación absoluta de los mismos: están completamente locos y tontos y habría que internarlos en un manicomio ${ }^{17}$. Pero en su larga vida, Cardoso nunca había conocido a ningún ateo auténtico. Lo que sí recordaba eran encuentros de antaño con personas «qui animi immortalitatem negabant, aut de illa dubitabant», y además, identificaba algunas ideas relacionadas, como el rechazo de la providencia divina ${ }^{18}$. En su «Lamentacion decima», Jerónimo Gracián también enfocaba la negación de la inmortalidad del alma y presentaba manifestaciones afines como la propagación de la «ley natural». A diferencia del carmelita, Cardoso era más preciso y distinguía

\footnotetext{
${ }^{15}$ Geronymo Gracián, Diez lamentaciones, del miserable estado de los Atheistas de nuestros tiempos (Bruselas, 1611).

${ }^{16}$ Acerca de estas y otras formas de irreligión, véanse Julio CARO BAROJA, Las formas complejas de la vida religiosa (Religión, sociedad y carácter en la España de los siglos XVI y XVII) (Madrid, 1978) págs. 197-206, y De la superstición al ateísmo. Meditaciones antropológicas ( $3^{\text {a }}$ ed., Madrid, 1986) págs. 239-281; John EdwARDs, «Religious Faith and Doubt in Late Medieval Spain», Past \& Present 120 (1988) págs. 3-25, y Stuart B. Schwartz, All Can Be Saved. Religious Tolerance and Salvation in the Iberian Atlantic World (New Haven-London, 2014).

${ }^{17}$ Isaac CARdoso, Philosophia Libera (Venecia, 1673) -«De Existentia Dei», págs. 726-730; el ataque aparece en las págs. 729-730.

${ }^{18}$ CARdoso, Philosophia, pág. 730.
} 
claramente esos conceptos del ateísmo ${ }^{19}$. Y efectivamente, es el ideario de corte deísta que detectamos en el mundo ibérico del seiscientos, Fernando Cardoso lo conocería en algunos círculos judeoconversos antes de emigrar de España a mediados del siglo XVII ${ }^{20}$. Pero para localizar el origen de esas corrientes, hay que remontarse a la centuria anterior.

En 1532, el historiador y humanista portugués João de Barros (14961570) publicó Ropicapnefma -obra rara con un título todavía más raro ${ }^{21}$ que es una composición (poco conforme a las reglas de la gramática

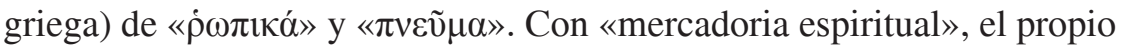
autor proporcionó la traducción y presentó el tema de su libro, que en buena parte trata de ideas, creencias y actitudes rechazadas por el sentido común cristiano. En una obra erasmista y bastante oscura al mismo tiempo, Barros arroja luz sobre la sociedad portuguesa de su tiempo y refleja tanto unos corrientes judaizantes como ciertas tendencias de desvinculación religiosa. Israël S. Révah veía el texto de Barros sobre todo como un intento envangelizador dirigido a los cristianos nuevos portugueses ${ }^{22}$. Es una interpretación posible, pero Ropicapnefma con su forma alegórico-dialógica no ofrece mensajes claros. Sin embargo, resulta notable la presentación del judaísmo y de ciertas formas de incredulidad en un contexto común. Pero ¿en qué medida el libro de Barros reflejaba la realidad concreta de una desvinculación religiosa en los ambientes conversos lusitanos del siglo XVI? Realmente, no conocemos casos sustanciales hasta bastante más tarde ${ }^{23}$ ¿Es ese silencio la prueba de una falta de irreligión,

19 Cardoso, Philosophia, pág. 730.

${ }^{20}$ Acerca de su biografía, vid. Yosef Hayim Yerushalmi, From Spanish Court to Italian Ghetto. Isaac Cardoso: A Study in Seventeenth-Century Marranism and Jewish Apologetics (New York-London, 1971).

${ }^{21}$ Joã [sic] de BArros, Ropicapnefma (Lisboa, 1532).

22 Israël S. RÉvAH, «Le colloque Ropicapnefma de João de Barros. Genèse, structure et technique», en Études portugaises, ed. Charles Amiel (Paris, 1975) págs. 155-183; otra buena introducción la encontramos en Charles Ralph Boxer, João de Barros. Portuguese Humanist and Historian of Asia (New Delhi, 1981) págs. 47-64.

23 En el ambiente de los cristianos nuevos trasmontanos, nos hemos encontrado con un vecino de Torre de Moncorvo que, en una visita pastoral de 1552-1553, fue testificado de haber dicho «q[ue] na[o] auia mais q[ue] nacer e morer». Processo, Luís Vaz, Lisboa, 1557, Arquivo Nacional da Torre do Tombo, Lisboa, Tribunal do Santo Ofício, Inquisição de Lisboa, proc. 12301. 
o nos encontramos ante una variante del camuflaje religioso que cobraba importancia por toda Europa en aquellos años $?^{24}$ No lo sabemos.

Indicios más palpables de incredulidad se detectan finalmente en el Brasil de mediados de los años 90, cuando en Olinda varias personas testificaron contra Bento Teixeira (ca. 1561-1600) por librepensador. Como consecuencia, el cristiano nuevo sufrió un proceso inquisitorial en Lisboa. Habiendo finalmente confesado su adherencia al judaísmo, el autor de la Prosopopeia -obra fundacional de la literatura brasileña- fue reconciliado en 1599. Si bien las ideas más radicales de Teixeira sólo las conocemos a través de las diversas testificaciones, estas tienen demasiado peso para no darles importancia. Según las mismas, el cristiano nuevo se perfila como una persona entre dos religiones, cuyas bases comunes está empezando a cuestionar ${ }^{25}$.

Como Bento Teixeira, Uriel, alias Gabriel, da Costa (c. 1584-1640) nació en Oporto, pero unos veinticinco años más tarde. Su vida turbulenta, que llevó al cristiano nuevo de Portugal a Amsterdam, estuvo presidida por su espíritu crítico. Exame Das tradições Phariseas -título de su obra publicada en 1623- ya señala la constante de la trayectoria intelectual de Costa: en un proceso cada vez más extremo, examina las fuentes de la religión, cuyas bases se le desmoronan. Costa es radical en el sentido estricto de la palabra, va a las raíces de la fe, que descarta sucesivamente: llega del cristianismo al judaísmo rabínico y de allí -a través del repudio de la Ley oralfinalmente a una religión basada en la razón. Ahí, encontramos el rechazo de la revelación, la negación de la inmortalidad del alma y la entronización de la «ley natural» como autoridad exclusiva -algunas de las «mercancías espirituales» que ya se vislumbraban en la obra de Barros- $-^{26}$.

\footnotetext{
${ }^{24}$ Perez Zagorin, Ways of Lying. Dissimulation, Persecution, and Conformity in Early Modern Europe (Cambridge, Mass.-London, 1990).

${ }^{25}$ Cfr. Lúcia Helena Costigan, Through Cracks in the Wall. Modern Inquisitions and New Christian Letrados in the Iberian Atlantic World (Leiden-Boston, 2010) págs. 79124, y José Antônio Gonsalves de Mello, Gente da Nação. Cristãos-novos e judeus em Pernambuco, 1542-1654 (Recife, 1989) págs. 81-115.

${ }^{26}$ Vid. Jean-Pierre Osier, d'Uriel da Costa à Spinoza (Paris, 1983); Carl GebHardt (ed.), Die Schriften des Uriel da Costa (Amsterdam et al., 1922); Herman P. SALOMON y Isaac S. D. SAssoon (eds.), Uriel da Costa. Examination of Pharisaic traditions. Exame das tradições phariseas (Leiden et al., 1993), e Israël S. RÉvaH, Uriel da Costa et les Marranes de Porto. Cours au Collège de France, ed. Carsten L. Wilke (Paris, 2004).
} 
Para Carl Gebhardt (1881-1934), editor de las obras de Costa, el asunto estaba claro: el origen del desarrollo intelectual de nuestro deísta se encontraba en la conciencia escindida de los cristianos nuevos ${ }^{27}$. Gebhardt marcó una pauta. A continuación, un «marranismo» más o menos extendido, una mentalidad específica entre dos religiones, fue vinculado con toda una serie de manifestaciones literarias, con actitudes críticas, subversivas y renovadoras, en las que se anunciaría un pensamiento moderno. Asimismo, se ha afirmado cada vez más una ambigüedad de la situación social y mental de los cristianos nuevos que excluiría identidades inequívocas ${ }^{28}$.

Israël S. Révah también partía de Carl Gebhardt, pero negaba que una conciencia conflictiva con tendencia a la irreligión fuese un fenómeno extendido entre los cristianos nuevos. Simultáneamente, señalaba que la desvinculación religiosa del seiscientos tenía un lejano origen en la actitud heterodoxa entre judíos y conversos ibéricos antes de la expulsión. Pero ¿se puede trazar tal línea de continuidad? Y ¿realmente fue tan decisiva la condición «marrana» para la ruptura religiosa de hombres como Uriel da Costa? ${ }^{29}$ Tanto este como Bento Teixeira recibieron una formación académica sólida ${ }^{30}$. Y en los estudios de filosofía y medicina,

\footnotetext{
${ }^{27}$ GeBhardt, Die Schriften des Uriel da Costa, págs. XIX-XXXIII.

${ }^{28}$ Para nuestro enfoque, son importantes las publicaciones de Yirmiyahu Yovel, cuyos títulos ya son reveladores: The Other Within. The Marranos. Split Identity and Emerging Modernity (Princeton-Woodstock, 2009); Spinoza and other Heretics, t. 1: The Marrano of Reason (Princeton, 1989); así como el libro de Gabriel Albiac, La sinagoga vacía. Un estudio de las fuentes marranas del espinosismo (ed. orig.1987, Madrid, 2013).

${ }^{29}$ Después de Yitzhak Baer, ese «averroísmo» judío bajomedieval ha sido tematizado repetidas veces; un ejemplo lo encontramos en Francisco Márquez Villanueva, «"Nasçer e morir como bestias" (criptojudaísmo y criptoaverroísmo)», en Los judaizantes en Europa y la literatura castellana del Siglo de Oro, ed. Fernando Díaz Esteban (Madrid, 1994) pags. 273-293. Yosef KAPLAN presenta una imagen más variada de la situación en «Foi et scepticisme dans la diaspora des nouveaux-chrétiens des débuts de l'Europe moderne», en La diaspora des «Nouveaux-Chrétiens», ed. Francisco Bethencourt (= Arquivos do Centro Calouste Gulbenkian 48 [Lisboa-Paris, 2004]) págs. 21-40: 23-31; como Révah, traza una línea de continuidad hasta épocas posteriores en págs. 31-40. Los planteamientos de Israël S. RÉvaH están reunidos en Des marranes à Spinoza. También Yirmiyahu Yovel, en su análisis del «marrano» Spinoza, se remonta al siglo XV (Spinoza, págs. 85-127).

${ }^{30}$ Para sus biografías, véanse las notas 26 y 25 , respectivamente.
} 
según Orobio de Castro, se hallaba el origen de la «apostasia y herejia» de algunos contemporáneos suyos. Sabía de lo que hablaba, pues como cristiano, él mismo había recibido aquella formación académica, y con su crítica, estaba pensando en algunas personas concretas ${ }^{31}$.

\section{Estudiantes en Alcalá}

Alrededor de 1625, dos jóvenes se marcharon de Madrid a Alcalá de Henares para estudiar medicina. Luis Enríquez de Fonseca (1612-?) y su hermano menor Rodrigo (1614-?) eran oriundos de San Felices de los Gallegos (Salamanca), donde su padre había sido corregidor de la casa de Alba, mientras que el abuelo materno de ambos servía como médico de cámara del poderoso duque. Ambas ramas de la familia estaban marcadas por una serie de procesos inquisitoriales y su memoria colectiva incluso recordaba algunas víctimas mortales. Los antecedentes de estos cristianos nuevos nos llevan al noreste portugués del quinientos, pero su lejano origen hay que buscarlo principalmente en Castilla, de donde se pasaron tantos judíos al país vecino en $1492^{32}$.

Cuando Luis y Rodrigo Enríquez de Fonseca llegaron a Alcalá, los dos hermanos eran bien conscientes de su condición social, y en el ambiente universitario se relacionaron rápidamente con otros cristianos nuevos de origen portugués. A través de la documentación universitaria, se perfila claramente un círculo de estudiantes que en los años anteriores y posteriores a 1630 estudiaron en las facultades de artes y medicina. Natalia Muchnik, quien más detenidamente ha enfocado a este grupo, ve en el encuentro sobre todo un proceso de socialización religiosa de

\footnotetext{
${ }^{31}$ Révah, Spinoza et Prado, pág. 90 (apéndice documental), acerca de de la vida de Orobio de Castro, véase la biografía importante de Yosef KaPLan, From Christianity to Judaism. The Story of Isaac Orobio de Castro, trad. del hebreo (Oxford et al., 1989); sobre los estudios de Orobio, vid. págs. 8-15 y 23.

32 Markus SchreIBER, Marranen. Eine Familie im Schatten der Inquisition, 14971688 (München, 2013) págs. 42-56, 59-60, 69-76, 92-103, 110-113 y 116. Acerca de las fechas de nacimiento, vid. Registro de bautismos, San Felices de los Gallegos, 1570-1613, Archivo Diocesano de Ciudad Rodrigo, lib. 688, fol. 328r-v, y Registro de bautismos, San Felices de los Gallegos, 1613-1659, Archivo Diocesano de Ciudad Rodrigo, lib. 689 , fol. 4 r.
} 
unos conversos todavía muy jóvenes que se iniciarían y reforzarían mutuamente en su criptojudaísmo. No hay pruebas, pero a la vista de las circunstancias, no queremos descartar esta interpretación ${ }^{33}$. Sin embargo, sospechamos que allí había más: una iniciación de otra índole, que tenía que ver con la vida académica.

En la España de los siglos XVI y XVII, el campo donde principalmente se mostraron innovaciones científicas e intelectuales era la medicina, cuyos mayores avances en la Península se producían en las universidades de Valencia y Alcalá de Henares ${ }^{34}$. Indudablemente, en el seiscientos -mucho más que en la centuria anterior- reinaba la tradición médica con sus príncipes Hipócrates, Galeno y Avicena, pero en la primera mitad del siglo, tanto las nuevas corrientes del siglo XVI como los desarrollos más actuales estaban presentes $^{35}$. En la Universidad Complutense de aquella época, ese espíritu abierto lo encarnaba sobre todo Pedro Miguel de Heredia (15791655), quien como titular de una cátedra de prima (1623-1643) era el maestro más destacado de nuestro círculo de estudiantes cristianos nuevos ${ }^{36}$. El eminente profesor en los años alrededor de 1630 tenía toda una serie de colegas, sobre los que hay menos informaciones ${ }^{37}$. Una noticia, sin embargo, llama la atención. En la Philosophia libera de Isaac Cardoso se menciona un «Barreda Complutensis Medicus, ac Philosophus subtilis in manuscriptis de temperamentis», quien pertenecería al círculo de los atomistas ${ }^{38}$. Y

\footnotetext{
${ }^{33}$ Acerca de este círculo, véase infra.

${ }^{34}$ Cf. José María López PIÑERo, Ciencia y técnica en la sociedad española de los siglos XVI y XVII (Barcelona, 1979) y Medicina e historia natural en la sociedad española de los siglos XVI y XVII (Valencia, 2007), y Natalia MuchNIK, Une vie marrane. Les pérégrinations de Juan de Prado dans l'Europe du XVII siècle (Paris, 2005) págs. $72-74$ y 351-364.

${ }^{35}$ Muchnik, Prado, págs. 72-74. Véase también Luis S. Granjel, La Medicina española del siglo XVII (= Historia general de la Medicina española 3 [Salamanca, 1978]); acerca de la panorámica intelectual general, véase Jean-Pierre ScHOBINGER (ed.), Die Philosophie des 17. Jahrhunderts, t. 1: Allgemeine Themen. Iberische Halbinsel. Italien (= Grundriss der Geschichte der Philosophie - Ueberweg [Basel, 1998]) págs. 319-511.

${ }^{36} \mathrm{El}$ «Prudentissimus Doctus [...] Magister meus semper cum honore memorandus» sería recordado decenios más tarde por Luis EnRíQuEz DE FonsECA, Novae securae curationis Podagrae: Libellus I. [...] (Nápoles, 1687) pág. 8.

${ }^{37}$ Luis Alonso Muñoyerro, La Facultad de medicina en la Universidad de Alcalá de Henares (Madrid, 1945) págs. 197, 207-211, 217-218, 222-223 y 227-229.

${ }^{38}$ CARdoso, Philosophia, págs. 4-5.
} 
efectivamente, encontramos a este Miguel de Barreda en Alcalá como catedrático de medicina antes y después de $1630^{39}$.

Hay otra noticia valiosa en la Philosophia libera, que menciona a un segundo atomista complutense ${ }^{40}$. Sobre este, Pedro Fernández de Torrejón (1594-1645), sabemos más. No era médico, sino jesuita, teólogo y filósofo, y nos ha dejado una obra bastante amplia. En ella, aunque no se presenta como auténtico atomista, manifiesta un interés muy pronunciado por la esencia de la materia, que para él estaba compuesta de una manera especial. ¿Fueron estas especulaciones discrepantes con el hilemorfismo aristotélico que le causaron dificultades nada desdeñables? Sabemos que la Compañía le expulsó de sus filas por negarse a retractarse de ciertas posiciones filosóficas, aunque más tarde fue readmitido. Además, el índice de la Inquisición española prohibiría en 1707 uno de los libros del jesuita, quien publicó tratados sobre física y dialéctica aristotélica. Fernández de Torrejón enseñaba antes y probablemente también después de 1630 en la facultad de artes de la Complutense, donde ocupó posteriormente una cátedra de teología. Es muy probable que nuestros protagonistas estudiaran con él $1^{41}$. Sobre los otros profesores que alrededor de 1630 ocupaban en Alcalá las cátedras de lógica, dialéctica, física y metafísica no sabemos mucho $^{42}$. Uno de los doctores era Pedro Caballero, otro Francisco de Montemayor. ¿Quién era este enseñante de filosofía con un nombre de cierto tufillo converso? No lo sabemos. Lo que sí podemos decir con certeza es

\footnotetext{
${ }^{39}$ Sobre Barreda y sus sucesores inmediatos, vid. Muñoyerro, La Facultad de medicina, págs. 207-211.

${ }^{40}$ Cardoso, Philosophia, págs. 4-5.

${ }^{41}$ Petrus Ferdinandius Torreion, Expositio in vniversam Aristotelis Dialecticam (Alcalá de Henares 1626); Philosophia antiqva ex Arist. et D. Thom. ad octo libros phisicorvm. Expositivis dispvtationibvs envcleata (Alcalá de Henares, 1639), y Philosophia antiqva ex Arist. et D. Thom. ad libros de ortv et interitv. Expositivis dispvtationibvs envcleata (Alcalá de Henares, 1641). En los dos últimos libros, se encuentran sus especulaciones intensas sobre la materia y su conocimiento del atomismo. Véanse además Gonzalo DíAz DíAz, Hombres y documentos de la filosofía española, t. 3 (Madrid, 1988) pág. 178; Juan URrizA, La preclara Facultad de Artes y Filosofia de la Universidad de Alcalá de Henares en el Siglo de Oro, 1509-1621 (Madrid, 1942) págs. 334-335. y 515, y Muchnik, Prado, pág. 354. En el índice de la Inquisición de 1707, Fernández de Torrejón aparece en el segundo tomo en la página 139 con su publicación de 1639.

${ }^{42}$ Sobre la facultad hasta 1621, vid. UrRIZA, Facultad de Artes.
} 
que a las clases de los dos profesores de filosofía acudieron asiduamente Luis y Rodrigo Enríquez de Fonseca y algunos de sus compañeros ${ }^{43}$.

¿Quien más pertenecía a ese grupo? En primer término, hay que nombrar a Juan de Prado (ca. 1612-1669), que muchos años más tarde alcanzaría cierta fama como «corruptor» de Spinoza. Posiblemente, el único de nuestros estudiantes que, a pesar de un estatuto de limpieza de sangre, consiguió entrar en un colegio universitario. Como Prado y los Enríquez de Fonseca, sus compañeros Jerónimo Gómez Chaves (ca. 1610-?), Agustín Suárez (ca. 1613-?) y Sebastián Méndez (ca. 1595?-?) pasaron en Alcalá por la facultad de artes para luego seguir en la de medicina. Sólo allí, encontramos a Diego Duarte Serrano (ca. 1608-?), Juan Baptista Rodríguez y Jorge Núñez, quienes probablemente habían adquirido su formación propedéutica en otra universidad. En cambio, está documentada la presencia en la facultad de artes de Diego Ruiz de Espinosa y Duarte Méndez (ca. 1611-?). Este posteriormente estudió medicina en Valencia y Ávila, donde obtuvo el título de doctor.

Los núcleos sociales alrededor de los que cristalizó este círculo de cristianos nuevos se conformaban por lazos familiares que no sólo relacionaron a Luis y Rodrigo Enríquez de Fonseca sino también a Juan de Prado y Jerónimo Gómez Chaves (si bien en un grado de parentesco menor) ${ }^{44}$. Así, al combinar la documentación universitaria con otras fuentes -sobre todo inquisitoriales- detectamos una realidad de nuestros estudiantes que era bien diferente de la vida oficial universitaria. Sin embargo, esas relaciones sociales y circunstancias biográficas a su vez sólo nos presentan una fachada, detrás de la cual se esconden ideas, creencias y mentalidades.

No conocemos muchos documentos de la época que echen luz sobre la vida estudiantil más allá de los hitos de la carrera académica. Una de esas pocas fuentes es el diario de Girolamo da Sommaia (1573-1635), que a principios del seiscientos acudía a las aulas salmantinas para estudiar derecho. En su crónica bastante amplia, el joven florentino desplegaba una fascinante panorámica que iba desde la rutina cotidiana hasta sus aventuras

\footnotetext{
${ }^{43}$ Muchnik, Prado, págs. 70-72 y 82-103.

44 Vid. Muchnik, Prado, págs. 43-45, 68, 70-72, 74-79, 82-103, 346 y 361-364; además de Schreiber, Marranen, págs. 116-118, y Markus SchreIBER, Marranen in Madrid, 1600-1670 (Stuttgart, 1994) págs. 168, 171-174 y 236-237.
} 
intelectuales y sexuales. Sommaia compartía los intereses con sus compañeros en un ambiente universitario muy animado. No faltaban estudiantes y visitantes extranjeros. Libros y manuscritos de todo tipo, incluso prohibidos, iban como moneda corriente de mano a mano ${ }^{45}$. Por aquellos años, también en las orillas del Tormes, Andrés López de Fonseca (1584-?) seguía la carrera de derecho. Ya hemos mencionado al padre de los hermanos Enríquez de Fonseca, que después de sus estudios entró al servicio del duque de Alba. La biblioteca que el Santo Oficio le secuestró a mediados del siglo es un impresionante testimonio de la talla intelectual de este hombre, que obtuvo su formación decisiva en Salamanca ${ }^{46}$. Entre ese tiempo y los estudios de sus hijos distan unos 25 años y 250 kilómetros, pero ¿era tan diferente el ambiente complutense alrededor de 1630 de la vida universitaria salmantina a principios del siglo? A la vista de las diversas circunstancias, no creemos que los estudiantes en la Alcalá de los años 20 y 30 del siglo XVII se moviesen en un mundo académico muy cerrado.

Aquí, podría terminar nuestra historia. Pero hay un dato que llama la atención. En el ambiente ibérico del XVII, detectamos a unos librepensadores con una formación académica común. Se trata de cinco cristianos nuevos que se encontraron alrededor de 1630 en Alcalá y pertenecieron al círculo de estudiantes que acabamos de señalar. ¿Hay que buscar el origen de su inquietud intelectual en sus días estudiantiles compartidos en Alcalá de Henares? Es muy posible, aunque no tenemos ninguna prueba definitiva de ello. Lo que sí podemos presentar son indicios. Para eso, hay que reconstruir unas vidas bastante extraordinarias.

\section{TRAYECTORIAS PROFESIONALES E INTELECTUALES}

Juan de Prado es el más conocido de nuestros protagonistas. Durante sus años complutenses, coincidió con Orobio de Castro, que desde 1635 estudió artes y medicina en Alcalá. En 1638, Prado se doctoró en Toledo

\footnotetext{
${ }^{45}$ George Haley (ed.), Diario de un estudiante de Salamanca. La crónica inédita de Girolamo da Sommaia (1603-1607) (Salamanca, 1977).

${ }^{46}$ Schreiber, Marranen, págs. 95-96. Para su situación sociocultural y su biblioteca en 1652, vid. Secuestro de bienes, Andrés de Fonseca, Madrid, 1652-1662, Archivo Histórico Nacional (Madrid), Inquisición, leg. 1896, exp. 2, fols. 1r-17v.
} 
y posteriormente practicó como médico en la alta Andalucía. Para esos años, está testimoniado su criptojudaísmo, pero hay información de que simultáneamente cultivaba ideas deístas. Nombrado médico de cámara de Domingo Pimentel de Zúñiga (1585-1653), en 1653 Prado llegó a Roma con el cardenal y futuro embajador en la Santa Sede; de allí, se marchó al año siguiente a Hamburgo para convertirse al judaísmo. Poco después, se estableció entre los judíos sefarditas de Amsterdam, donde sus ideas de librepensador produjeron no poco escándalo. Estableció una relación con el joven Spinoza, sobre quien tuvo cierta influencia, y no escondió sus convicciones en el seno de la comunidad judía. Spinoza fue expulsado en 1656, Prado dos años más tarde. Este pasó el decenio siguiente en el ambiente ibérico de Amberes, donde murió en 1669 en un accidente ${ }^{47}$. En los años 60, Juan de Prado y Orobio de Castro, que entretanto también se había convertido al judaísmo, estaban inmersos en una discusión por escrito sobre sus convicciones religiosas y filosóficas. En la misma, nuestro librepensador residente en Amberes se perfila como claro deísta, que recusa la tradición religiosa del judaísmo como de cualquier otra religión positiva y se proclama seguidor de una «religión natural» ${ }^{48}$.

A mediados de los años 50, Isaac Orobio de Castro sufrió un proceso inquisitorial en Sevilla, en el que ya atestiguó el deísmo de Juan de Prado. En cuanto al desarrollo intelectual del amigo, resulta cierta vaguedad. Si en una testificación Orobio de Castro situó la ruptura religiosa de Prado en los años complutenses, en otra contó que había percibido por primera vez esas nuevas ideas hacia 1643 en Lopera (Jaén). Fuera como fuese, es muy posible que el deísmo de Prado se remontase a sus días universitarios. Pero hay más. Ante la Inquisición, Orobio de Castro testificó

\footnotetext{
${ }^{47}$ MuchniK, Prado; acerca de la relación Prado-Spinoza, vid. también: Jonathan I. IsRael: Radical Enlightenment. Philosophy and the Making of Modernity, 1650-1750 (Oxford et al., 2001) págs. 172-174.

${ }^{48}$ RévaH, Des marranes à Spinoza; los documentos editados por RÉVAH se encuentran en Spinoza et Prado, y en «Aux origines de la rupture spinozienne: Nouveaux documents sur l'incroyance dans la communauté judéo-portugaise d'Amsterdam à l'époque de l'excommunication de Spinoza», Revue des Études Juives 123 (1964) págs. 359-431; vid. también Muchnik, Prado, págs. 448-478. Acerca del ambiente, véase Adam Sutcliffe, «Sephardi Amsterdam and the European Enlightenment», en Jewish Studies at the Turn of the Twentieth Century. Proceedings of the 6th EAJS Congress, Toledo, July 1998, t. 2, eds. Judit Targarona Borrás y Ángel SÁEnZ-BAdillos (London et al., 1999) págs. 399-405.
} 
también contra Diego Duarte Serrano. Este -recordemos- también había pertenecido al círculo de nuestros estudiantes complutenses y estaba presente en el encuentro ocurrido alrededor de 1643: allí, se proclamó seguidor de los planteamientos radicales de Prado. Desafortunadamente, no sabemos mucho sobre Duarte Serrano, que nació en Lisboa o en Brasil. Hacia 1630 estudiaba medicina en Alcalá, más tarde se casó con una pariente de Prado y practicó como galeno en Andalucía. Al tiempo de la testificación contra él, se encontraba refugiado en Francia ${ }^{49}$.

A principios de los años treinta, Duarte Serrano y Prado estudiaban medicina junto con Luis y Rodrigo Enríquez de Fonseca. Estos eran nietos del ya mencionado doctor Enrique Jorge Enríquez (ca. 1555-1622), que había gozado de mucho prestigio como médico de cámara del duque de Alba ${ }^{50}$. Nuestros dos estudiantes siguieron el ejemplo del abuelo. Rodrigo Enríquez de Fonseca en la Complutense pasó por la facultad de artes para estudiar a partir de 1629 medicina y graduarse finalmente como licenciado. Parece que continuó su formación en la Universidad de Valencia durante algún tiempo. En 1635, se trasladó con Cristóbal de Torres (1573-1654) a Bogotá, donde sirvió al arzobispo de médico de cámara. En la capital de Nueva Granada, el joven galeno desplegaba una actividad notable, que culminó con su nombramiento de protomédico y catedrático de medicina. Enríquez de Fonseca estaba bien integrado en la élite novogranadina y parece que no se vio afectado por las masivas campañas que en aquellos años dirigían los tribunales inquisitoriales de América contra los cristianos nuevos. Sin embargo, en 1643, de golpe, abandonó Bogotá para volver a Europa. Resulta que en ese momento Enríquez de Fonseca estaba siendo duramente atacado ${ }^{51}$. En una carta enviada a Madrid, el presidente de la audiencia advertía de que se trataba de un "portugués, cristiano nuevo, perjudicial y escandaloso» ${ }^{52}$.

${ }^{49}$ Vid. Muchnik, Prado, págs. 45, 341-343; Israël S. Révah: Des marranes à Spinoza, pág. 279, y el proceso, Francisco Gómez Romano, Cuenca, $1^{a}$ aud., 17 de agosto de 1654, Archivo Diocesano de Cuenca, Cuenca, Inquisición, leg. 492, exp. 6569, fol. 65r. Acerca de la vida de Orobio de Castro, vid. Kaplan, Orobio de Castro.

${ }^{50}$ SchreIBER, Marranen, págs. 96-103.

${ }^{51}$ SCHREIBER, Marranen, págs. 133-137.

${ }^{52}$ La carta data del 13 de agosto de 1643; cf. Juan Manuel PACHECO, Los jesuitas en Colombia, t. 1 (Bogotá, 1959) pág. 539.

SEFARAD, vol. 77:2, julio-diciembre 2017, págs. 375-403. ISSN: 0037-0894. doi: 10.3989/sefarad.017.013 
Después de su vuelta a España, Rodrigo Enríquez de Fonseca se convirtió en hombre de negocios. Junto con su hermano Luis y el padre, se encargó de arrendamientos de rentas, de aprovisionamientos de Corte y tropas y de asientos. Sin embargo, debido a unas circunstancias económicas poco favorables y a la fuerte persecución inquisitorial de los cristianos nuevos, la empresa familiar se hundió. Rodrigo Enríquez de Fonseca tuvo que huir del Santo Oficio y en 1653 se marchó, con su mujer y un cuñado, por segunda vez a América. Finalmente, los tres fueron apresados en 1656 en Chile y procesados en Lima. Las complicadas causas duraron años, hasta que en 1664 nuestro médico y su esposa salieron reconciliados en un auto de $\mathrm{fe}^{53}$.

Cuando Enríquez de Fonseca entró en las cárceles secretas, estaba testificado de judaizante, pero en 1661, confesó algo muy diferente. En un primer momento, se reveló como librepensador que no reconocía la revelación divina sobrenatural. La biblia como tal no posibilitaba el conocimiento ni de Dios ni de la historia, que de ninguna manera se remontaba a Adán. No era cierta la inmortalidad del alma, el pecado original no existía. Razón y «ley natural» eran las únicas instancias fiables para saber de este y del otro mundo. En sus confesiones, Enríquez de Fonseca desarrolló un claro ideario deísta. Pero ahí no se terminaba el asunto. Al mismo tiempo, el médico manifestó su vacilación entre catolicismo, judaísmo y deísmo y expresó profundas dudas respecto a cualquier verdad religiosa. Sin embargo, junto a ese escepticismo se vislumbran tendencias fideístas. Como única constante de su trayectoria espiritual, nos presenta a la Virgen, que siempre le había guiado. Según Enríquez de Fonseca, su deísmo se remontaba hasta sus días estudiantiles. Pero no nos lleva a Alcalá, sino a la Valencia de los años 30, y nos presenta a un mallorquín como instigador intelectual. Sería este Baltasar Casáus -o mejor, Casals- quien habría introducido a nuestro estudiante en el ideario deísta. Sin embargo, quedan algunas dudas. Volveremos al asunto ${ }^{54}$.

Enríquez de Fonseca pasó su penitencia en el Santo Oficio de Sevilla, donde le encontramos en los años 1665-66. Durante el día, no sólo podía

\footnotetext{
${ }^{53}$ SCHREIBER, Marranen, págs. 151 y 159-164.

${ }^{54}$ Libro de testificaciones, Madrid, 1663; audiencias, Rodrigo Enríquez de Fonseca, Lima, 4 y 11 de marzo de 1661, Archivo Histórico Nacional (Madrid), Inquisición, lib. 1134 , fols. $168 \mathrm{v}, 172 \mathrm{r}-\mathrm{v}$ y $174 \mathrm{r}-175 \mathrm{v}$.
} 
salir de la cárcel sino también de la ciudad. Además, al tribunal acudían «personas graves» que presionaban en favor del reconciliado para que pudiese ejercer como médico. Parece que finalmente consiguió el privilegio insólito del Consejo de Inquisición. ¿Quiénes eran esos valedores que le apoyaban? Posiblemente hay que buscarlos en el entorno de la casa de Medinaceli. Ya lo veremos. En la segunda mitad de los años 60, Enríquez de Fonseca vivía en Écija, luego volvió a Sevilla, donde le encontramos en $1670^{55}$.

En aquel año, en Granada se publicaron las Instancias a vn papel muy docto del doctor D. Rodrigo Enriqvez. Con este libro, nos encontramos otra vez ante unos acontecimientos que requieren atención. Cuando nuestro médico residía en Écija, examinó a una monja dominica enferma. Parece que Enríquez de Fonseca discrepaba del diagnóstico general y no quería reconocer que ninguna fuerza satánica operase en la mujer. En 1669, presentó un pequeño tratado con sus ideas a la universidad de Osuna y un catedrático de medicina respondió en nombre del profesorado. La publicación de 1670 contiene los dos textos. La refutación, que identifica una posesión de la religiosa por el diablo, va en primer lugar y sale vencedora, pero la posición contraria sigue como anejo. A primera vista, Enríquez de Fonseca exponía una interpretación médica, pero en la misma se encontraban ideas claramente vinculadas con sus confesiones de Lima. Deconstruía la visión mágica y reducía los fenómenos observados en la dominica a causas naturales. Ahí, ningún demonio o diablo obraba. Pero había más. En algún momento, el médico insinuó que tampoco Dios intervenía. El Deus otiosus de los deístas se vislumbraba ${ }^{56}$.

El texto de Enríquez de Fonseca no contenía ninguna defensa abierta de la «ley natural», pero sus posiciones olían a herejía y en el contexto de su biografía cobraron un significado bastante claro. ¿Realmente, no se sabía con quién se trataba? Pocos años antes, los inquisidores habían

${ }^{55}$ Carta, Inquisición de Sevilla al Consejo, 6 de julio de 1666, Archivo Histórico NaCional (Madrid), Inquisición, leg. 3000, sin numeración ni foliación; vid. también la nota 56 .

${ }^{56}$ Ivan Balthazar DE HARIZA, Instancias a vn papel muy docto del doctor D. Rodrigo Enriqvez, medico que fue en la Ciudad de Ezija, y aora lo es de Sevilla. Sobre averigvar la cavsa de vnos accidentes que entonces padecia vna señora Religiosa Dominica en el Convento del Espiritu Santo de dicha Ciudad (Granada, 1670). 
advertido de las «cavilaciones de este sujeto» ${ }^{57}$. La publicación granadina de 1670 rebatía los planteamientos de Enríquez de Fonseca, pero al mismo tiempo se presentaba como una discusión de tono cortés entre dos partes. Esta impresión la refuerza el prefacio, en el que el prologuista elogiaba la erudición de los dos autores de la obra. Sabía de lo que hablaba, pues él mismo era un galeno de mucha cultura. Se trataba de Duarte Núñez de Acosta (ca. 1606-ca. 1685), que en aquellos años servía como médico de cámara del duque de Medinaceli. Es posible que tuviera origen judío. Probablemente, algo tuviese que ver con las intercesiones ante los inquisidores en favor de Enríquez de Fonseca de mediados de los años $60^{58}$.

En 1670 , la pista de nuestro galeno se pierde, reapareciendo en Italia algunos años más tarde. Para entender mejor ese último viraje biográfico de Enríquez de Fonseca, conviene enfocar la vida de su hermano mayor. Luis Enríquez de Fonseca en los años anteriores y posteriores a 1630 recorrió las facultades de artes y medicina de la Universidad de Alcalá. A continuación, estuvo inmerso en el mundo de los arrendamientos y asientos durante muchos años. Alrededor de 1640, le encontramos en Andalucía. Probablemente, desde entonces participó en las empresas nada desdeñables de su padre. Como su hermano y otros familiares, fue apresado por el Santo Oficio a mediados del siglo y salió con una abjuración de levi en un auto de fe de la Inquisición granadina en $1655^{59}$.

A continuación, Enríquez de Fonseca emigró a Nápoles. La capital virreinal le ofrecía un ambiente ibérico, al que no sólo pertenecían los círculos gubernamentales hispánicos sino también conversos de origen diverso. Se relacionó con ambas esferas y entabló contactos con la élite intelectual de la ciudad. Una sociabilidad que se veía favorecida por su condición de médico. En 1676, consiguió una cátedra de medicina de la universidad de Nápoles. Además, publicó algunas obras de diversos gé-

\footnotetext{
${ }^{57}$ Carta, Inquisición de Sevilla al Consejo, 6 de julio de 1666, ArCHIVo Histórico NACional (Madrid), Inquisición, leg. 3000, sin numeración ni foliación.

${ }^{58}$ Sobre este médico de la casa de Medinaceli, vid. también Luis Charlo Brea (ed.), Poesías latinas de Duarte Núñez de Acosta (Cádiz, 1993); con una introducción valiosa, vid. también KaPlan, Orobio de Castro, págs. 71-72 y 88.

${ }^{59}$ SCHREIBER, Marranen, págs. 116-118 y 151.
} 
neros $^{60}$. En sus escritos de medicina, Enríquez de Fonseca mostraba una actitud que combinaba la tradición con las nuevas tendencias científicas. Al mismo tiempo, el cristiano nuevo enlazaba perfectamente con la vibrante vida intelectual de su nueva patria. No sólo era catedrático de universidad sino también miembro de la importante «Accademia degli Investiganti», que se consagraba al progreso de las ciencias. Uno de sus fundadores fue Tommaso Cornelio (1614-1684), personaje destacado de la vida intelectual, en el que se reunieron la filosofía natural renacentista del sur de Italia, el cartesianismo moderno y los avances científicos de Galileo. Como catedrático de medicina, Cornelio era colega de Enríquez de Fonseca, pero parece que a ambos los unían también lazos de $\operatorname{amistad}^{61}$.

Nuestro médico cristiano nuevo cultivaba relaciones con otros «Investiganti», y también con miembros del gobierno y de la corte virreinal. Además, conocía bien a los López de Castro y a los Cortizos, que asimismo se habían trasladado de Castilla a Nápoles ${ }^{62}$. Este poderoso clan cristiano nuevo a su vez mantenía contactos con Tommaso Cornelio y con el obispo y erudito universal Juan Caramuel y Lobkowitz (1606-1682), que

${ }^{60}$ Lvis Enríquez de Fonseca, Señor. El Licenciado Don Luis Enríquez de Fonseca dice a V. Magestad [...] [Nápoles, 1672]; Tratado y discurso sobre la moneda de el Reyno de Napoles. Su estado, el origen de sus daños. El remedio para su consumo (Nápoles, 1681); Ocios de los estudios. Versos i discursos philologicos (Nápoles, 1683), y Novae securae curationis Podagrae: Libellus I. [...] (Nápoles, 1687). Sus obras son una fuente fecunda acerca de sus ideas y de su vida en Nápoles. Vid. también SCHREIBER, Marranen, págs. 176-182.

${ }^{61}$ Vid. EnRíQuez de Fonseca, Libellus I, y Ocios, págs. 110-112; Thomas Cornelius, Progymnasmata Physica. His accessere Ejusdem Authoris Opera quaedam Posthuma numquam antehac edita (Nápoles, 1688); IsRAEL, Radical Enlightenment, págs. 49-58, y Paolo Cristofolin,, «Die Accademia degli Investiganti», en Die Philosophie des 17. Jahrhunderts, t. 1: Allgemeine Themen. Iberische Halbinsel. Italien, ed. Jean-Pierre SCHOBINGER (= Grundriss der Geschichte der Philosophie - Ueberweg [Basel, 1998]) págs. 937-946; vid. también Marta CAVAzZA, «Il soggiorno di Tommaso Cornelio a Bologna (1647)», Nouvelles de la République des Lettres 2 (1984) pags. 7-32, y Oreste TrabucCo, «L'Invenzione della tradizione» nella filosofia meridionale da Telesio agli Investiganti», Bruniana \& Campanelliana. Ricerche filosofiche e materiali storico-testuali 16 (2010) pags. 177-187.

${ }^{62}$ Los contactos de Enríquez de Fonseca se reflejan sobre todo en sus publicaciones. Sobre los López de Castro y los Cortizos, vid. Schreiber, Marranen in Madrid, págs. 66-76.

SEFARAD, vol. 77:2, julio-diciembre 2017, págs. 375-403. ISSN: 0037-0894. doi: 10.3989/sefarad.017.013 
era otro de los «Investiganti» y que también formaba parte del círculo de Enríquez de Fonseca ${ }^{63}$. ¿Había allí unos lazos de patronazgo entre algunos conversos ricos y un círculo científico-filosófico avanzado? En todo caso, nos encontramos ante un ambiente social e intelectual al que pertenecían italianos, conversos de origen portugués y cristianos viejos españoles ${ }^{64}$.

Y allí apareció también Rodrigo Enríquez de Fonseca, quien a mediados de los años 80, y por un corto espacio de tiempo, ocupó una cátedra de medicina en la Universidad de Nápoles ${ }^{65}$. Él y su hermano encontraron en esos años una atmósfera intelectual muy estimulante. De Luis Enríquez de Fonseca no tenemos ninguna manifestación abierta de deísmo, pero se movía en unos círculos en los que seguramente se discutían tales temas. Para ello, Nápoles era un sitio más apropiado que Castilla. Sin embargo, a finales de los años 60 la «Accademia degli Investiganti» fue disuelta por el virrey, aunque el círculo siguió reuniéndose. Por último, la Inquisición procedió contra cuatro letrados de ese ambiente, que, en los años 80 y 90, fueron procesados por atomistas y ateístas. A continuación, el movimiento de los «Investiganti» se disolvió ${ }^{66}$. No queda claro si por entonces los hermanos Enríquez de Fonseca aún vivían.

De nuestros cinco protagonistas que estudiaron alrededor de 1630 en Alcalá, falta uno. Y este es un caso especial. Fue Israël S. Révah quien llamó la atención sobre Juan Piñero como instigador intelectual de Juan

\footnotetext{
${ }^{63}$ Vid. Connelius, Progymnasmata, págs. 57-58 (1 $1^{a}$ foliación) 110-111 (2a foliación), y Ioannes Caramuel, Primus Calamus, t. 1: Primus Calamus ob oculos ponens Metametricam [...] (Roma, 1663) passim, t. 2: Primus Calamus ob oculos exhibens Rhythmicam [...] ( $2^{a}$ ed., Campagna,1668) págs. 522-524.

${ }^{64}$ A este círculo, asimismo pertenecía el funcionario virreinal y hombre de letras Manuel García de Bustamente, que era amigo íntimo de Enríquez de Fonseca. Al dedicarle un texto médico, escribe sobre él: «Domum tuam scientiarum Academiam, \& Aticas noctes illas memorare, cunctis eruditis, nec non mihi solatium est dolore mistum, quale ab Lusitanis significanter dicitur ter saudades: [...].» ¿Se reunieron los «Investiganti» en casa de este hombre? La cita y más información: EnRíqueZ de FonSECA, Libellus I, después de pág. 184 (1ª foliación); vid. también Enríquez de FonseCA, Ocios, $3^{\text {a }}$ foliación.

${ }^{65}$ SCHREIBER, Marranen, pág. 181.

${ }^{66}$ Vid. Max. H. Fisch, «The Academy of the Investigators», en Science, Medicine, and History. Essays on the Evolution of Scientific Thought and Medical Practice, written in honour of Charles Singer, ed. E. Ashton Underwood, t. 1 (London et al., 1953) págs. 521-563, y Luciano Osbat, L'Inquisizione a Napoli. Il processo agli ateisti 1688-1697 (Roma, 1974).
} 
de Prado. Además, reunió alguna información inquisitorial según la cual un homónimo de Sevilla era amigo y compañero de estudios de Rodrigo Enríquez de Fonseca. Los dos Piñeros fueron médicos. Parecía razonable suponer que se trataba de una misma persona ${ }^{67}$. Pero ¿quién fue ese misterioso hombre? En su biografía sobre Juan de Prado, Natalia Muchnik ya estaba muy cerca de este personaje sin llegar a identificarle ${ }^{68}$.

Juan Piñero -o más exactamente, Juan Baptista Piñero- nos ha dejado tres libros que se publicaron en Andalucía a mediados del siglo XVII. Quien lea estos textos, enseguida reconocerá al personaje «loco en su discurir, intrepido en su hablar, amigo de novedades, solicitador de paradoxas» del que habla Orobio de Castro. No obstante, queda por resolver una incógnita. Si nuestro hombre fue compañero de estudios de Enríquez de Fonseca y conoció a Prado, parece probable que estuviera con ellos en Alcalá, pero durante los años en cuestión, no encontramos allí a ningún Piñero. Sin embargo, había un Juan Baptista que sí pertenecía al círculo de los hermanos Enríquez de Fonseca. Ese lisboeta se llamaba -como ya queda indicado- Rodríguez, y sospechamos que él era Piñero ${ }^{69}$. No tenemos ninguna prueba definitiva, pero contamos con más indicios. Señalemos sólo uno.

Entre nuestro círculo de estudiantes complutenses se encontraba también Diego Ruiz de Espinosa, que procedía de Molina de Aragón

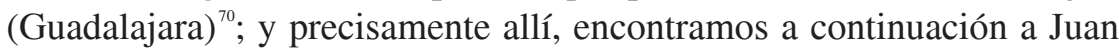
Baptista Piñero como médico de la villa. Era amigo de Diego Sánchez Portocarrero (1607-1666); este funcionario real e historiador en su obra sobre el señorío de Molina incorporó algunas consideraciones del galeno, que explicó «con agudeza y nouedad digna de Estampa» la profunda influencia del ambiente y del clima sobre las gentes de la región. Solo pocas líneas las dedicaba el autor a su amigo Piñero, pero en ellas ya aparecía el médico que solía discurrir como filósofo ${ }^{71}$.

\footnotetext{
${ }^{67}$ RÉvah, Des marranes à Spinoza, págs. 271-272.

${ }^{68}$ MuchNik, Prado, págs. 345-348.

${ }^{69}$ Muchnik, Prado, págs. 90-91.

${ }^{70}$ Muchnik, Prado, pág. 91.

${ }^{71}$ Diego Sánchez Portocarrero, Historia del Señorio de Molina. Segunda parte, t. 1 (mediados del siglo XVII), Biblioteca Nacional de España (Madrid), Manuscritos, 1556, fol. $9 \mathrm{v}$.
} 
Cuando Sánchez Portocarrero terminó su amplia historia de Molina, Piñero probablemente ya vivía en Andalucía. Allí, a mediados del siglo, la comunidad de los médicos fue sacudida por un debate acerca del sitio correcto donde aplicar la sangría, un debate en el que se enfrentaron reformadores y tradicionalistas. Estos últimos veían amenazadas las bases de su arte profesional y de la fe ${ }^{72}$. En 1655, Juan Baptista Piñero empezó a participar en la discusión. Entonces estaba vinculado a la casa de Medina Sidonia como médico de cámara del hijo primogénito del duque. Su relación con el poderoso linaje continuó al entrar más tarde al servicio del convento de San Isidro del Campo, que era una fundación bajomedieval de los Medina Sidonia. Hacia 1660, vivía allí, en las cercanías de Sevilla, a mediados del siglo se encontraba también en la metrópoli misma, y parece que durante algún tiempo residió en otro lugar de la baja Andalucía ${ }^{73}$.

En sus publicaciones, Juan Baptista Piñero se mostraba bastante reacio a suministrar informaciones autobiográficas. Sin embargo, esos libros nos revelan algo de su ideario. La entrada del médico en la discusión de los galenos andaluces sobre la sangría se dio con cierto retraso. Con su Concordia de la controversia sobre el sitio de la sangria de 1655, Piñero quería conciliar las posiciones de los dos bandos opuestos, pero no lo consiguió. Todo lo contrario, acabó enzarzándose en una discusión cada vez más agresiva con un colega. De ese debate, resultaron dos publicaciones más de Piñero ${ }^{74}$. ¿Quién era el adversario? Ya le conocemos, se

\footnotetext{
${ }^{72}$ Kaplan, Orobio de Castro, págs. 67-75. Kaplan describe la fase clave de la discusión en 1652-53, pero el debate seguía a fuego lento.

${ }^{73}$ Estos datos biográficos los sacamos sobre todo de sus tres publicaciones, dentro de las que se encuentran en los inicios, y también hay información en la parte principal del escrito de 1659, que no tiene foliación, y en los folios 3v, 6r y 9v del libro de 1661; para los datos bibliográficos, véase la nota 74 infra. Véase también Muchnik, Prado, págs. 245 y 347-348, así como Duarte NúñEz de Acosta, Clava de Alcides [.... (Jerez de la Frontera, 1660) inicio.

${ }^{74}$ Juan Baptista PIÑERO, Concordia de la controversia sobre el sitio de la sangria, en los principios de las enfermedades (Sevilla, 1655); Propvgnacvlo de la Concordia, sobre la Controversia del sitio de la sangria, en los principios de las enfermedades superiores (Écija, 1659) y Escvdo de la verdad, que desvanece clavas, si en lo sophistico Hercvleas, siempre en lo vero pigmeas: y aniqvila cierta anvlacion de vn medico joven, incierta en lo qve promvlga, anulada en lo que enxerta (Sevilla, 1661). Los libros son muy raros: los dos últimos se encuentran en la Biblioteca de Andalucía en Granada, y del último se ha conservado sólo un fragmento.
} 
trataba del doctor Duarte Núñez de Acosta, que pertenecía al grupo de los tradicionalistas ${ }^{75}$. No podemos entrar aquí en los detalles médicos del enfrentamiento, pero sí queremos arrojar alguna luz sobre la base de las ideas de Piñero.

Como todos los galenos españoles de la época, nuestro autor se atiene principalmente a las autoridades antiguas y medievales, sin embargo, conoce bien los desarrollos científicos desde el renacimiento. Piñero cita toda una serie de médicos «modernos» como Girolamo Fracastoro (1477-1553), Francisco Vallés (1524-1592) o Johan Baptista van Helmont (1580-1644), además, su segundo libro de 1659 va precedido de una carta dedicatoria de Gaspar Bravo de Sobremonte Ramírez (1603-1683). Este prestigioso catedrático vallisoletano y posterior médico de cámara de Felipe IV y Carlos II intentaba de reconciliar la tradición de su arte con algunos de los recientes avances científicos; así, divulgaba el descubrimiento de la circulación de la sangre, y parece que se encontraban en un intercambio profesional de cierta regularidad con Piñero. En la obra de este, asimismo aparece Daniel Sennert (1572-1637). El conocimiento del catedrático de Wittenberg -destacado representante de la iatroquímica y del atomismo- no solo es testimonio del horizonte intelectual de nuestro protagonista sino también otro indicio de unos estudios de Piñero en Alcalá: Sennert tuvo una influencia nada desdeñable en Pedro Miguel de Heredia, cuyos alumnos complutenses Luis y Rodrigo Enríquez de Fonseca también conocieron al galeno alemán muy bien ${ }^{76}$.

El espíritu abierto e inquieto de Piñero se muestra con particular claridad en sus posiciones médicas. En contra de la tradición, que con respecto a las enfermedades superiores defendía la sangría en el brazo, nuestro galeno propagaba un procedimiento diferenciador: en ciertos casos la terapia era necesaria arriba; en otros, abajo, en el tobillo. En el contexto de esta discusión científica, Piñero revela ciertos fundamentos de su ideario. Es muy

${ }^{75}$ Piñero hizo imprimir una carta de Duarte Núñez de Acosta en su libro de 1659. Este a su vez publicó un escrito contra el adversario, titulado Clava de Alcides.

${ }^{76}$ Las citas se encuentran a lo largo de los tres libros de Piñero, Sennert también aparece en las publicaciones de Luis y Rodrigo Enríquez de Fonseca. Acerca de Pedro Miguel de Heredia, véase Josep Bernabéu Mestre, «Tradición y renovación en el pensamiento y obra del Dr. Pedro Miguel Heredia (1579-1655)», Dynamis. Acta Hispanica ad Medicinae Scientiarumque Historiam Illustrandam 7/8 (1987/88) págs. 117-143. 
crítico con el «saber» de su profesión, la «Medicina Galenica no es sciencia rigurosa». Las doctrinas que no se basan en la experiencia las rechaza como opiniones, y «opinion excluye sciencia». Por eso, Piñero critica las generalizaciones, hay que prestar atención a las particularidades, hay que diferenciar y matizar. Pero no se para ahí, sino que se revela como auténtico escéptico que en algunas consideraciones epistemológicas pone radicalmente en duda nuestra capacidad de conocimiento. Somos prisioneros en un cuerpo que con sus sentidos poco acceso tiene al mundo exterior. Finalmente, en su Escvdo de la verdad de 1661 el médico expresa su admiración por Quod nihil scitur de Francisco Sanches (1550-1623) e invoca De incertitudine et vanitate omnium scientiarum et artium liber de Heinrich Cornelius Agrippa von Nettesheim (1486-1535) ${ }^{77}$.

¿Qué consecuencias tenía ese escepticismo radical? En sus discusiones médicos, Piñero se muestra poco reticente a desarrollar y defender sus planteamientos científicos y a menudo es tan doctrinario como los adversarios. ¿Y las consecuencias en lo religioso? A la vista de la dura crítica de Orobio de Castro, parece poco probable que Piñero fuese fideísta. Aparte de su ataque a la tradición médica, sería un escepticismo que incluía una desvinculación religiosa que tanto provocó a Orobio de Castro. Y ahí habrá que buscar también el origen de la «corrupción» de Juan de Prado. Pero ¿en qué creía Piñero? ¿Era escéptico y agnóstico? ¿Deísta o ateísta? El caso es que el Santo Oficio empezó a interesarse por él, aunque cuando los inquisidores sevillanos quisieron prenderle en 1665 , ya estaba muerto desde hacía tres años ${ }^{78}$.

\section{ORÍGENES DE LA INCREDULIDAD}

Hemos llegado al final de la historia de los cinco médicos nacidos a principios del siglo XVII. Si bien todos ellos estuvieron más o menos hispanizados, permanecían vinculados al mundo de los cristianos nuevos

\footnotetext{
${ }^{77}$ Su ideario se despliega en los tres textos; los pasajes más interesantes se encuentran en la Concordia, fols. 4r-5v, y en el Escvdo de la verdad, fol. 3v. Orobio de Castro, quien, en el bando de Núñez de Acosta, también había participado en el debate sobre la sangría, seguramente conocía la Concordia de Piñero; sobre su papel en la discusión, vid. KAPLAN, Orobio de Castro, págs. 67-75.

${ }^{78}$ RÉvaH, Des marranes à Spinoza, pág. 271.
} 
portugueses. A diferencia de los conversos castellanos, con fuertes tendencias a la integración, el ambiente lusitano se caracterizaba por el peso del criptojudaísmo, la importancia de las actividades mercantiles y financieras y una orientación más internacional. Ciertamente, ese trasfondo común marcó profundamente a nuestros protagonistas, pero el lazo que más estrechamente los unía fueron las experiencias y orientaciones intelectuales compartidas: estudiaron juntos en Alcalá de Henares y posteriormente manifestaron ideas que los alejaron del judaísmo sin acercarlos a la fe cristiana. Tres eran deístas -y Luis Enríquez de Fonseca probablemente cultivase también este ideario-. Queda el «maldito y detestable» Juan Baptista Piñero. Al leer sus textos y reunir las informaciones sobre él, reconocemos a un personaje que recuerda lejanamente a Mefistófeles: «Soy el espíritu que siempre niega ...». Es probable que el desarrollo intelectual de los cinco tuviera un origen común en el ambiente estimulante de la Complutense alrededor de 1630. A lo mejor, un hombre como Juan Baptista Piñero, posiblemente mayor que los otros ${ }^{79}$, desplegaba alguna influencia sobre sus compañeros. Sin embargo: puede ser que Rodrigo Enríquez de Fonseca no empezara a entrar en contacto con el deísmo hasta su estancia en Valencia y allí un Baltasar Casals ${ }^{80}$ lo «pervirtiese». Además, Piñero quizás nunca estudiase en Alcalá y solamente Juan de Prado recibiese la influencia de él.

Fuera como fuese, el asunto resulta notable. Al repasar el panorama ibérico de los siglos XVI y XVII, llama la atención que el deísmo principalmente se manifestó entre los conversos. Al mismo tiempo, esa desvinculación religiosa estuvo relacionada con el pensador que en el siglo XVII con más fuerza rompió con el legado judeo-cristiano. En Amsterdam, Spinoza tuvo el caso de Uriel da Costa ante sus ojos, y además, mantuvo una relación de algunos años con Juan de Prado. Sin embargo, hay que tener cuidado con las generalizaciones. Spinoza encontró su inspiración

\footnotetext{
${ }^{79}$ En 1661 habla de su «ancianidad decorada de tantas canas como las mias»; $c f$. Piñero, Escvdo de la verdad, fol. 6r.

${ }^{80}$ De él no hemos encontrado la más mínima huella; $c f$. Amparo Felipo, Francisca Miralles y Francisco Javier Peris, Estudiantes y probanzas de cursos en la Universidad de Valencia (1561-1707) (Valencia, 2013), y Amparo Felipo OrTs, La Universidad de Valencia durante el siglo XVII (1611-1707) (Valencia, 1991). Desde luego, se impone la sospecha de que este Casals era uno de los chuetas mallorquines, sin embargo, tampoco allí aparece.
} 
principal en el cartesianismo. Y, que entre los cristianos nuevos existiese una extendida «escisión mental» responsable de una modernidad más o menos revolucionaria, nos parece dudoso. Crítica de la biblia, deísmo e ideas similares fueron fenómenos muy raros entre los conversos, y el origen de dichas corrientes no se debe buscar exclusivamente en el «marranismo». Entraba en juego una cultura académica con su tradición filosófica y científica que -sobre todo con el aristotelismo- ponía al alcance de la mano el instrumental intelectual necesario para una crítica fundamental de la religión. Sin embargo, no había automatismo. Hemos mencionado repetidas veces a Isaac Orobio de Castro e Isaac Cardoso. Aunque ambos tuvieron el mismo trasfondo social, religioso e intelectual de nuestros protagonistas, optaron por el judaísmo ${ }^{81}$.

El ambiente de los cristianos nuevos ibéricos fue un mundo particular; no obstante, sus manifestaciones de incredulidad enlazaron con desarrollos intelectuales en otros países y ambientes. Fueron los decenios entre finales del siglo XVI y mediados del XVII en los que las nuevas ideas se concretizaron. En ese lapso de tiempo, el deísmo surgió en diversos sitios de Europa. Desde luego, eran ambientes distintos y existían diferencias. Así, llama la atención la importancia que tenía el tema de la inmortalidad del alma para nuestros librepensadores cristianos nuevos. Pero había un denominador común y existía un fondo similar, que se caracterizaba por unas tradiciones religiosas y académicas europeas, a las que se sumaron las experiencias de los constantes conflictos confesionales y fenómenos particulares como el criptojudaísmo o el antitrinitarismo. Al lado del deísmo, apareció el panteísmo de Spinoza, que ejerció su fascinación en algunos, pero, a diferencia de otras ideas del filósofo, solo muy pocos seguidores encontró. Y ¿dónde quedaba el ateísmo? Entre los cristianos nuevos del XVI y XVII no lo hemos encontrado.

Quizá Juan Baptista Piñero lo profesase, pero no lo sabemos. Sigue siendo un personaje enigmático. En su Escvdo de la verdad, se nos presenta como hombre retirado en San Isidro del Campo y dedicado al «exercicio mental, con quietud, y paz». Cuando alrededor de 1660 empezó a escribir su último libro como respuesta a Duarte Núñez de Acosta, tuvo que interrumpir otras labores. Piñero estaba preparando algunos «frag-

\footnotetext{
${ }^{81}$ Acerca de las biografías de los dos hombres, vid. KapLan, Orobio de Castro, y Yerushalmi, Isaac Cardoso.
} 
mentos» para la imprenta ${ }^{82}$, pero murió poco después de la publicación del Escvdo de la verdad sin haber dado a conocer esos textos. Daríamos mucho por saber lo que contenían ${ }^{83}$.

Recibido: 27/07/2017

Aceptado: 30/11/2017

${ }^{82}$ PIÑERO, Escvdo de la verdad, prólogo y fol. 9v.

${ }^{83}$ Con la precariedad de los saberes y de la situación social, Piñero y sus compañeros pertenecerían a aquel «Wissensprekariat» analizado magistralmente en Martin Mulsow, Prekäres Wissen. Eine andere Ideengeschichte der Frühen Neuzeit (Berlin, 2012). 